\title{
THE CULTURAL AND CREATIVE TOURISM - SUSTAINABLE OPPORTUNITY FOR ECONOMIC DEVELOPMENT
}

\author{
Diana-Cristina PINTEA ${ }^{a *}$, Alina B $\breve{A D U L E S C U^{b}}$ \\ ${ }^{a, b}$ University of Oradea, Faculty of Economic Sciences, Romania
}

DOI: $10.24818 / \mathrm{IMC} / 2020 / 01.08$

\begin{abstract}
The last years were marked by the tourists' emancipation and their need for more meaningful experiences and so, particular activities based on the combination of cultural and experience tourism, were framed as creative tourism. Creativity shows up as the most suitable "tool" to satisfy tourists' complex demands by adding active participation which in turn, determines fulfilling experiences; by practicing creative tourism is avoided "the serial reproduction of mass cultural tourism, offering more flexible and authentic experiences which can be co-created between host and tourist" (Richards, 2011). Our interest regarding the creative tourism is based on its relationship with the creative economy; the creative and cultural industries on one hand, and the creative tourism, on the other hand, work interdependently, enhance each other, and possess the potential to transform socially and economically the place where they flourish. In this regard, the present paper aims to assess the relationship between the creative tourism and several Romanian creative cities, firstly by presenting practices of creative tourism from Romania and also other countries; secondly our analysis comprises the assessment of the local creative economies and also dimensions of the local tourism of the selected creative cities. The observation of the collected data doesn't link tourism to the highest values in terms of the local creative economies, but these aspects could represent unexplored potentials and need further research.
\end{abstract}

KEYWORDS: creativity, creative city, creative tourism, cultural tourism, heritage.

\section{INTRODUCTION}

Culture will never cease to amaze, entertain and raise interest and the most direct way to discover it is given by tourism. Accordingly to Pechlaner and Abfalter in Sigala \& Leslie, 2005, "societal tendencies such as a higher significance of culture and experience and the quest for identity have shown increased interest in cultural tourism (...) culture becoming an ever more important travel motive”. Other specialists noticed a significant interest for the cultural tourism among the younger well-educated tourists, frequently first-time visitors, whereas the more experienced travellers seek to enjoy a 'way of life' (McDonnell \& Burton in Sigala \& Leslie, 2005). The cultural tourists are rather people with higher levels of education and income (Richards, 2020b), and they consume places and tangible cultural heritage at an increasing pace, and so they "become blasé, tired of the same old thing, and search for the new and that which is different” (Sigala \& Leslie, 2005).

Based on these facts, a demand for more authentic experiences is rising, as well as a supply characterized by "increasing competition, need to create distinction, need to involve the citizen and the using the qualities of place" (Richards, 2020b) framing a new sector of tourism, the creative tourism, a niche within the cultural tourism (Al-Ababneh \& Masadeh, 2019).

\footnotetext{
* Corresponding author. E-mail address: dianna_sava@yahoo.com
} 
The creative tourism implies those activities based on the uniqueness of the experience, the meaning for and the self-expression of the tourist, who becomes an active performer in supplying, not only in the consumption of touristic services. The active consumer in tourism prefers rather the intangible forms of culture along with the "doing", the "living", much more than just "seeing".

Furthermore, culture and creativity work hand in hand together, in fact the cultural and heritage products represent results of the human creativity, which in turn is described by Bruno \& Canina (2019) as a "spontaneous act pushed by intrinsic motivation, through which the individual can improve itself and his world" through the resulted innovations. Hence creativity could be considered an engine of economic development mostly explored in the creative economy, whereas the focus is put on "the human resource, talent, intellect and creativity, as the main production factors. Creativity makes its presence felt in the combination of the production factors in any industry, but along with artistic and symbolic expressiveness, copyrights and specific production methods, outlines the creative and cultural industries” (Sava \& Bădulescu, 2018b). Subsequently, aiming development and promotion, various cities and regions emphasized the importance of creativity and creative industries in their strategies such as cities from Lithuania, Estonia, Denmark (Martinaityte \& Kregzdaite, 2015, Lorenzen \& Andersen, 2012).

The exploitation of the creative tourism brings benefits also to those locations less rich in tangible heritage due to its main purpose: the experience is crafted by the exchange of skills, knowledge and habits. Following these, any city, region or area, whatever urban or rural, could maximize its touristic potential by conducting various creative activities specific to the local culture for the reason that "for outsiders, the culture of an area can represent an attraction in and of itself... may seek exposure to local behaviours and traditions, to different ways of life or to vestiges of a vanishing lifestyle" (Fridgen in Sigala \& Leslie, 2005). Consequently, creativity proved to be a strategic tool in tourism as well, the creative tourism confirming the "growing integration between tourism and different place making strategies, including promotion of the creative industries, creative cities and the "creative class” (Richards, 2011).

\section{METHODOLOGY}

This paper represents the first step in a more elaborated research project and so, one of its aims is to present a literature review with the most important findings regarding the creative tourism. Secondly, international and national practices of creative tourism show the various ways in which this type of tourism can be explored. In the last part of this work, we analysed by observation of various data regarding the creative economies of several Romanian cities, and their tourism dimensions. The local creative economies are measured by reporting the absolute values to the number of inhabitants, in this way the collected data become more comparable. These absolute values comprise the number of employees of the creative - cultural industries and also, the recorded turnovers of these industries; it has to be strongly highlighted that the data collected are only from private companies. The comparability of these measures is ensured by using two indexes, the Creative employees index (number of employees / number of inhabitants * 1000) and the Creative Turnover index (turnover / number of inhabitants * 1000), the latter being expressed in thousands lei. On the other hand, it is important to assess the touristic potential of these creative cities, so the number of accommodation establishments / 100000 inhabitants and the number of nights spent in these establishments / 1000 inhabitants, were also took in consideration. These two dimensions also reported to the local population, as well, due to the comparability needed, but also for framing a picture with the business and job opportunities in tourism for each city. 


\section{THE CREATIVE TOURISM - AN EXPERIENTIAL TYPE OF CULTURAL TOURISM}

\subsection{The cultural tourism}

As any other type of tourism which implies the temporary leaving of the hometown in order to visit specific objectives, the cultural tourism stands out as "the movement of persons to cultural attractions away from their normal place of residence, with the intention to gather new information and experiences to satisfy their cultural needs” (Richards in Sigala \& Leslie, 2005). This type of tourism exploits the material culture (assets and the procedures of creating them) and also the spiritual culture of a place (science, literature and arts creations) representing a way of capitalizing its anthropic resources, both as citadel tourism and rural -ethnographic tourism (Vlăduțiu, 1976).

From another point of view, the cultural tourism is perceived "as the visit to and knowledge of cultural monuments and historic-artistic sites. It encompasses perceptions of a value-added experience for the tourist, which thus is associated with quality tourism" (Estrada-Gonzalez in Sigala \& Leslie, 2005). For instance, this concept is mentioned very often as "heritage and cultural tourism" and according to Christou heritage and cultural tourism combines the exploitation of the heritage and cultural attractions highlighting a distinction between those two; considering only the heritage attractions, these embody historic and archaeological sites and buildings (Christou in Sigala \& Leslie, 2005), determining the heritage tourism to be perceived as "mainly focusing on the past and on nostalgia (...) a form of special tourism that offers opportunities to portray the past in the present" (Christou in Sigala \& Leslie, 2005).

However, in order to consider a trip or a holiday a matter of cultural tourism it has to meet the three conditions, as Figure 1 presents below:

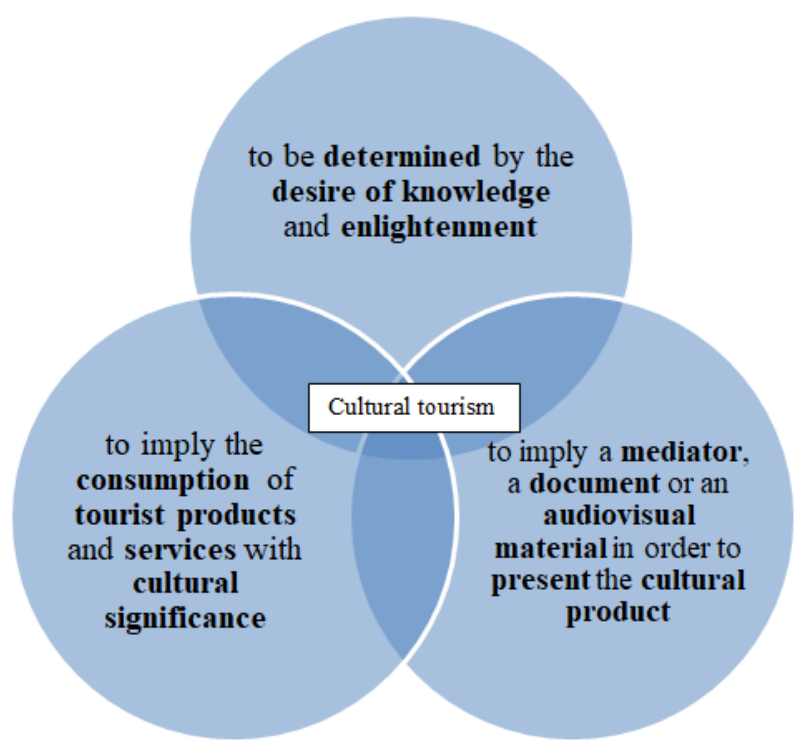

Figure 1. Conditions for framing tourism practices as cultural tourism Source: own elaboration

The motivation of travelling represents the crucial element in differentiating the cultural practice from the other types of tourism. The cultural tourist chooses between various motives, one of them being the exploration of the cultural and artistic heritage which enables the access to a broaden knowledge and ensures in this manner benefits for both, tourism and heritage. Their association provides commodities for the tourism industry, and on the other hand, the heritage is preserved in order to be valuable for the visitors' experiences. 
The cultural tourism employs both tangible and intangibles heritage; both types of heritage imply different ways of preservation, promotion and exploitation. While the tangible heritage materializes as monuments, buildings, historic sites and a lot more, the intangible heritage embodies customs and traditions. For example, the Romanian culture enjoys recognition from UNESCO (n.d.) for various intangible cultural heritage, such as: the ritual of Căluș (folk dance and music), Doina (grief folk music), Craftmanship of Horezu ceramics, Men's group Colindat (Christmas-time ritual), Lad's dances in Romania (men's folk dance), Traditional wall-carpet craftsmanship in Romania and the Republic of Moldova, and Mărțisor - cultural practices associated to the 1st of March (the offering and wearing a red and white thread). These intangible heritages could be exploited wherever in Romania without losing the sense of belonging, and with lower expenses, providing in the same time significant experiences and more direct perception of the Romanian culture.

Another essential aspect for the cultural tourism is represented by the status of European Capital of Culture; annually since 1985 within the European Union, one or two European cities are selected as European Capitals of Culture in order to "host a wide range of cultural events, performances, activities and projects with a strong European dimension (...) becoming one of the most prestigious and high profile cultural events in Europe" (EUROSTAT, 2019). This event takes place aiming to celebrate the diverse and heterogeneous European culture meanwhile the local economies are enhanced and promoted, by focusing on specific aspects, such as: richness and diversity of the European cultures; matters of cultural identity shared by Europeans; Europeans' sense of belonging to a common cultural area; culture's contribution to the development of cities (EUROSTAT, 2019). The most considerable positive impacts on the selected cities as European Capitals of Culture are recognized as economic, social and cultural benefits as Figure 2 presents below:



Figure 2. Positive impacts of European Capital of Culture status Source: adapted from EUROSTAT (2019)

Considering Romania, this country enjoyed having Sibiu selected as European Capital of Culture in 2007, the same year when Romania joined the European Union. The next occasion when a Romanian city will benefit from this status is approaching, Timisoara, a city from Western Romania, being one of the European cities selected as European Capital of Culture in 2021. This opportunity is auspicious not only for the local economy of Timisoara, but also for the whole Romanian economy, this kind of events having the potential to grow local consumption and steer the interest also for other Romanian regions.

\subsection{The creative tourism}

The creative tourism represents a new paradigm of tourism although the concept was mentioned for the first time in 1993 without being defined (Pearce \& Butler in Richards, 2011). The first and most accepted definition was given by Richards and Raymond, framing this new type of tourism as the "tourism which offers visitors the opportunity to develop their creative potential through active participation in courses and learning experiences which are characteristic of the holiday destination where they are undertaken” (2000). Furthermore, to the active participation is added another crucial feature: sustainability and so, another point of view emerges. In this new light, the creative tourism is perceived as "a more sustainable form of tourism that provides an authentic feel for a local culture through informal, hands-on workshops and creative experiences. Workshops take place in small groups at tutors' homes and places of work; they allow visitors to explore their creativity while getting closer to local people” (Raymond in Richards, 2011). 
Before creative tourism, travelling towards meaningful experiences was referred to as experiential tourism or known as an active type of leisure tourism, but in time, distinction was made between these concepts. What is more important to mention, is the distinction between experience tourism and the creative one; the experience tourism emerged within the experience economy, a paradigm characterised by the shift from "selling services to selling experiences" (Pine II \& Gilmo, 1998), whereas the creative tourism meets more specialised needs for experiences, these needs being more oriented towards culture, learning and living. We consider that the creative tourism is a type of tourism emerged from the combination of the cultural tourism and the experience one, as the following figure shows:

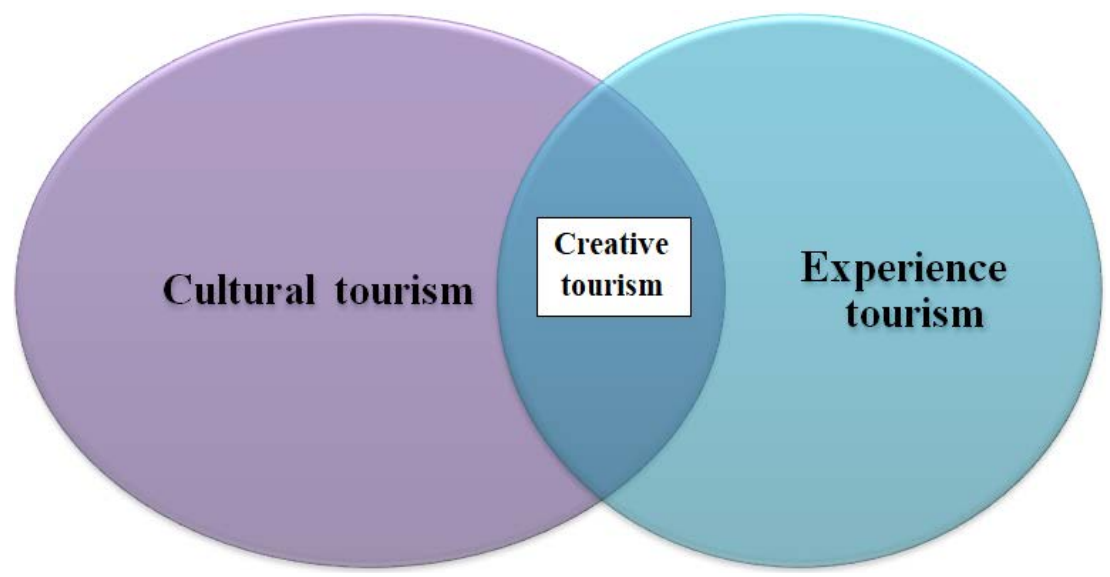

Figure 3. The creative tourism - a mixture of cultural tourism and experience tourism Source: own elaboration

The creative tourism is considered rather an extension of the cultural tourism (Richards in Richards \& Wilson, 2006), a provider of more meaningful experiences and a better understanding of the cultural activity meanwhile avoiding the serial reproduction of culture. Other specialists put the creative tourism into a brighter light than the cultural tourism, considering it a higher form of tourism, “an evolution of cultural tourism directed towards more engaged and authentic experiences” (D'Auria in Richards, 2011). But the creative tourism is not only learning other cultures by doing; it also means engaging in the local activities, living like the locals.

The most of the definitions emphasize the process without mentioning the importance of the place; its influence doesn't consist in the material aspects as long as these do not worsen the experience, but more the creativity of the place itself, as Richards highlighted "the creative tourism implies that not just the tourists need to be creatively involved, but the destination itself needs to become more creative in designing 'characteristic' experiences (...) linked to place, and which give creative tourists a specific motivation to visit" (Richards, 2011). So given the fact that the creative tourism implies conducting cultural and creative activities with the co-performance of the tourist, there are some aspects that must be kept in mind in order to avoid the serial reproduction, specifically: authenticity, diversity and sense of belonging.

The advantages brought by the creative tourism consist not only in new motives to attract visitors, job creation or culture preservation; this industry can develop in any area, urban or rural, and so, the latter could benefit more considering the fewer opportunities in contrast with cities. In this regard, Wisansing and Vongvisitsin highlighted some positive aspects of the creative tourism:

- Increased job opportunities for women;

- New business and working opportunities for the younger generation from villages;

- Higher demand for the local production (Richards, 2020b). 
The main characteristic of the creative tourism, the co-performance of the visitor, could create distress because the success of the activity relies on the ability of both actors (customer and supplier) to relate to each other and to make the encounter fulfilling for one, and profitable for the other.

\section{THE TOURISM AND THE CREATIVE INDUSTRIES}

Greg Richards appreciates creativity for its impact in renewing touristic products and services, improving the atmosphere of the cities, and also city branding (Happ \& Toth, 2017) due to its bidirectional relationship with tourism, "creativity provides activity, content and atmosphere for tourism and, tourism in turn, supports creative activities” (Richards, 2011).

Surprisingly, in several studies of urban economies, the tourism industry is "often listed as one of the creative industries (...) in some cases the definition of creative industries has been broadened to include tourism” (Bagwell, Bonink \& Hitters, Evans in Richards, 2011). This concern regarding the tourism and especially the creative one needs a detailed analysis, in order to consider or not the tourism a sector of the creative economy.

According to the creative economy's literature the creative industries are recognized as "those industries which use culture as input and have a cultural dimension, even if their productions are generally functional" (Croitoru et al. in Sava \& Bădulescu, 2018a). Besides their economic outcomes, the creative industries have a critical social role, these aiming "promote and maintain cultural diversity and to ensure democratic access to culture" (UNCTAD, 2008). Considering these aspects, we would incline to consider the creative tourism a creative industry, the OECD strengthening the conviction by defining the creative tourism "as a convergence of tourism and the creative economy generating knowledge based creative activities that link producers, consumers and places by utilising technology, talent or skill to generate meaningful intangible cultural products, creative content and experiences” (Richards, 2020b). Yet the creative tourism is not a creative industry, nor part of the creative economy; the creative tourism evolved within the cultural tourism which is clearly an industry of the service economy, whereas the cultural industries are included in the exhaustively named - creative industries. For us, the creative economy exploits differently the cultural - creative industries, the firsts being defined by cultural and symbolic expressiveness, and the latters by innovation and functionality. But the base is common and represents the reason why the creative tourism cannot be considered a creative industry: according to the very first definition of the creative industries given by the Great Britain’s Government, the creative economy is linked to those industries "which have their origin in individual creativity, skill and talent and which have the potential for wealth and job creation through generation and exploitation of intellectual property" (Higgs et al., 2008). Unquestionably, the creative tourism's activity employs a certain level of creativity and skills, but does not exploit the human intellect, and obviously, its products and services are not objects of the intellectual property rights.

However, the relationship between the creative economy and the creative tourism exists and it is extremely beneficial for both. The creative and cultural industries often mark places and transform them in famous destination, for example the film industry; we could name lots of places famous due to the films produced there: an island from Thailand is called James Bond Island (Hotels.com, n.d.) because some scenes of the movie were produced there; New Zealand is another famous destination thanks to the "Lord of the rings" trilogy - the impact of the trilogy on that area is so high that even if the last film was released almost twenty years ago, there are tours on the movie location (Lord of the rings, n.d.) still nowadays. Festivals of all sorts, music, film or gastronomy also increase the popularity of an area and determine the creation of a periodical habit to return in the same place. As we can see in these cases, the creative industries caused the emergence of the creative tourism practices which in turn provide the need of a continuous supply from the creative and cultural industries. 


\section{CREATIVE TOURISM OPPORTUNITES}

\subsection{International aspects of the creative tourism}

The first project considered to be specific to the creative tourism was the EUROTEX project, conducted during 1996-1999, involving Portugal, Finland and Greece, and it "identified the growing tourist interest in local vernacular culture, everyday life and the desire to become more involved through active creative learning experiences” (Richard, 2011). Anyway, Thailand was the destination which declared itself officially as the first creative tourism destination in Asia (Wattanacharoensil \& Schuckert in Richards, 2020b) due to the activities conducted in rural areas such as working in rice fields, elephant-handling, hill tribe embroidery, massage techniques and even coconut palm sugar production (Pattaya mail, n.d.)

Another example of tourists' interest in learning and practicing elements of other cultures, is given by the flamenco tourism, from Andalusia. Flamenco, as a folk dance associated with Southern Spain, represents one of the Spanish UNESCO intangible cultural heritages and is a well-known element of the creative tourism of the region due to the large number of classes, tours and flamenco products designed especially for tourists (Millán Vázquez de la Torre et al., 2019).

The creative tourism could be exploited in larger places designed to host various types of cultural activities, as in the case of The Farm Cultural Park in Sicily, Italy; this place emerged by renovating several abandoned buildings in the old town of Favara with the intent to regenerated the "territory and to give a city without a past, a present and a future" (Culture Action Europe, n.d.). The Farm Cultural Park functions since 2010 and attracts visitors from all around the world by hosting art exhibitions, cooking experiences, workshops and cultural events (Della Lucia \&Trunfio in Richards, 2020b).

A more evolved practice of the creative tourism implies a platform, and Barcelona Creative Tourism platform was first one, operating since 2005 (Creative Tourism Network, n.d.). Through this platform was established the connection between artists, locals and visitors, aiming "to offer the visitors the opportunity to discover the city of Barcelona and its surroundings in a creative way, to interact with the locals as well as to feel like locals themselves” (Barcelona creative, n.d.).

The active participation promotes the whole tourism industry because if a place is famous, it will rise the curiosity of other travellers too, both active and passive consumers. A Vietnamese study regarding the ceramic workshops pointed out that the recommendations are based on the positive memories, "that emotions and creative experience are positively related, and that creative experiences lead to a high level of intention to re-visit” (Ta and Yang, 2019).

\subsection{Aspects of the creative tourism in Romania}

In Romania, the concept of creative tourism is very little known and promoted, so we can barely name a few official destinations where the creative tourism could be practiced; the Romanian official tourism site doesn't even recognise this practice of tourism, promoting only the rural, urban, cultural, health, seaside tourism, ecotourism and adventure tourism (Romania Travel, n.d.). The industry of Art crafts rises interest in the visitors of Maramures, a region of Northern Romania, where the Center of Tourist Information of Negresti - Oas promotes as tourist attractions: cultural attractions (museums, exhibitions, ceramic art), monasteries and churches, mountain attractions, folklore and ethnography, and lastly, craftsmen and artisans (Turism Tara Oasului, n.d.). Within the cultural attractions, is presented the centre of ceramic, Vama, a place where tourist can craft pottery by themselves.

Another place where tourists can be actively involved in specific experiences is Arsenal Park. In this case, the creative tourism implies military activities. The warlike environment, program and activities are not a coincidence in that place; Arsenal Park is a holiday village built on the site of a former armament and ammunition factory (Arsenal Park, n.d.). We consider this park, even if it appears more suitable as a form of experience tourism, due to the place where it is established, this converted place 
acts like a creative place - a common feature of the creative tourism (Ferreira Carvalho et al., 2019), and due to the new skills development occurred during the stay. The concept is exceptional and unique in Romania due to its large and specialised offer; the accommodation keeps the military characteristics and the activities enjoy diversity, offering: climbing trails, archery tag, treasure hunts, shooting, group military training, military museum and a lot more.

Another possibility of living like the locals and experiencing the culture of the Romanian rural areas is given by the guest house "Casa Bătrână”, located in the village Zece Hotare from Western Romania (Wildventure, n.d.). This guest house offers accommodation in a restored old house, the furniture, the surroundings and all the other objects determining the traveller to experience the life of the Romanian villagers from a long time ago. Most of its tourists are nostalgic Romanian seeking for living like in the old times, but also foreigners who seek seclusion and the freedom of the simpler life.

Considering the actual pandemic and the restrictions of travelling abroad, many Romanian tourists had been left to satisfy their need for travel by visiting their own country. Romania enjoys numerous attractions, tangible and intangible heritage, mountain and sea destinations, also the demands for rural and urban tourism can be met inside the country, but concerning the creative tourism the options are limited. With or without the pandemic, the Romanian tourism has an unexploited potential in the sector of creative tourism, which could represent an option for development and continuity of the touristic activity for those destinations dependent on the season.

\subsection{Creative tourism in creative cities}

In this section we will analyze if there is any causality relationship between several Romanian creative cities and tourism. As an appropriate example for our study, we will consider the city of Obidos, Portugal, where the creative tourism flourished after 2001 when the municipality took actions towards promoting the city as a creative one and attracting members of the creative class, and so, developing its creative economy (Musikyan, 2016). The creative strategies determined to take place in January 2009, the “1st Creative Mayors' Summit: Small Cities for Creativity”, where the participants where mayors from Portugal, Spain, Italy, United Kingdom, Romania and Hungary, determining the international recognition of a little Portuguese town. During the years, Obidos has stood out as a creative city and its creative tourism has developed by fostering annual events such as: Christmas Village, Opera Festival, Chocolate Festival, June for Arts, Medieval Fair etc. (Musikyan, 2016).

Given this example and the fact that in Romania there are several cities with an important creative economy, we would consider important for our future research, to assess the creative economy of Bucharest, Cluj-Napoca, Timișoara, Iași, Brașov, Sibiu and Oradea, and also some aspects regarding their general tourism. We cannot distinguish particular practices in these cities but we assume there are conducted activities specific to the creative tourism considering that these seven cities are important economic, social and cultural centres in Romania (Sava, 2020).

In the followings we analyzed two measures of the local creative economies during 2015-2019, the number of employees and the recorded turnover, whereas the selected measures regarding the tourism potential, were number accommodation establishments and number of nights spent in the accommodation establishments. In order to ensure a higher accuracy of the data comparability, we reported these indicators to the number of inhabitants, so we will consider the Creative employees index and the Creative turnover index.

The Romanian creative economy finds its greatest developments in Bucharest, the capital of the country, and in Cluj-Napoca, a very important city of Western Romania, but considering the population of each city, we can look at Cluj-Napoca as to the creative pole of Romania, this fact being illustrated also in Figures 4 and 5. 


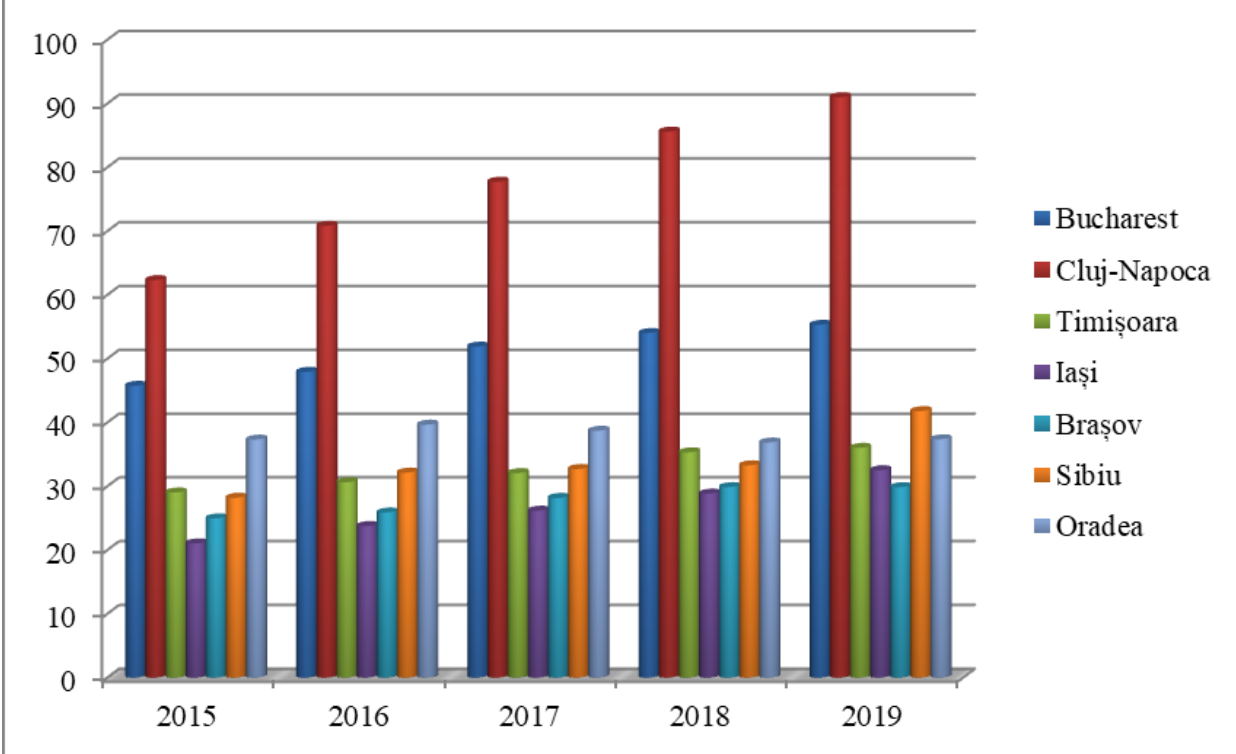

Figure 4. Creative employees index rate (number of employees / 1000 inhabitants)

Source: own elaboration using data from Borg Design (n.d.)

Analyzing these two figures, the creative economy flourishes in Romania recording annual increases, the most favourable cities being, after Cluj-Napoca and Bucharest, Timișoara, Oradea, Sibiu, Brașov and Iași.

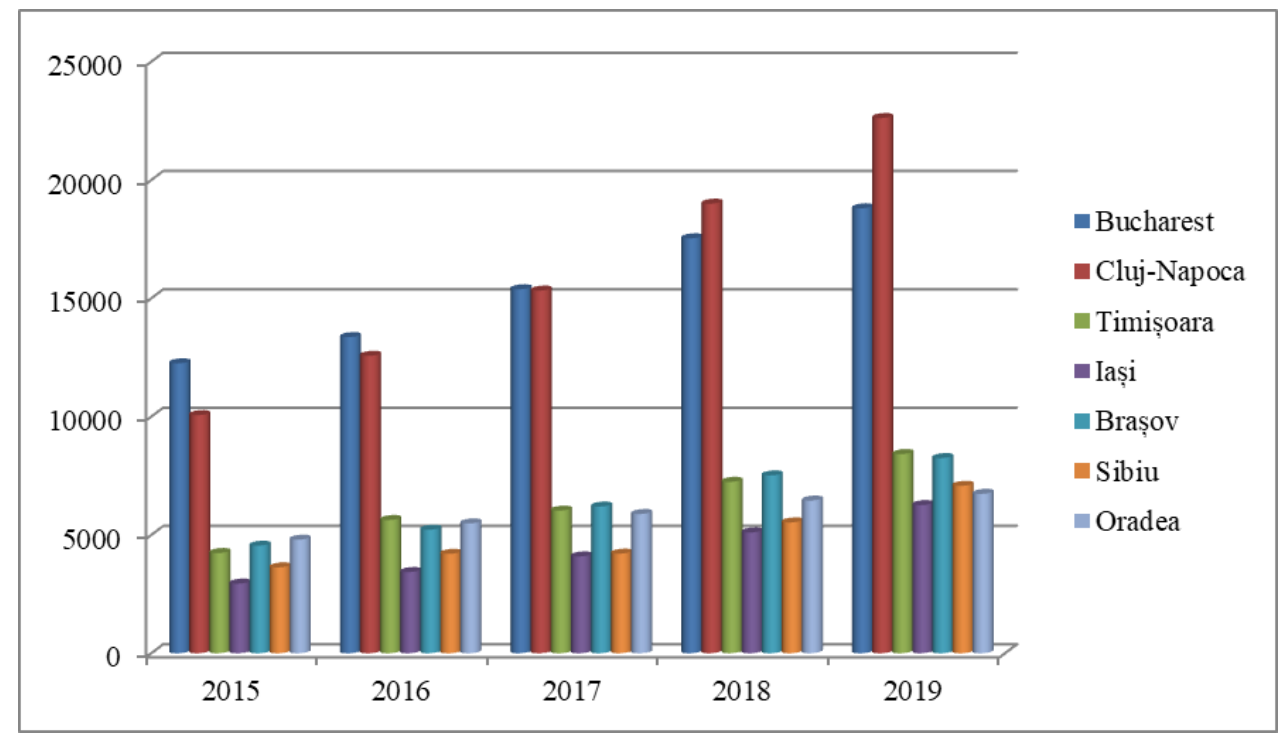

Figure 5. Creative turnover index

Source: own elaboration using data from Borg Design (n.d.)

Measuring the creative tourism's potential implies the general analysis of the urban tourism of the selected cities; the endowment of each town is considerable, but considering the actual size of each city, appears that the capital, Bucharest, has a low offer for accommodation, whereas Brașov and Sibiu stand out (Figure 6). Of course, these two cities have different motives of enjoying such large offers: in their area the mountain tourism is strongly developed and Sibiu is an important cultural centre (European Capital of Culture). In opposition with the measures of the local creative economy, it seems that Cluj-Napoca and Bucharest should improve their accommodation offer. 


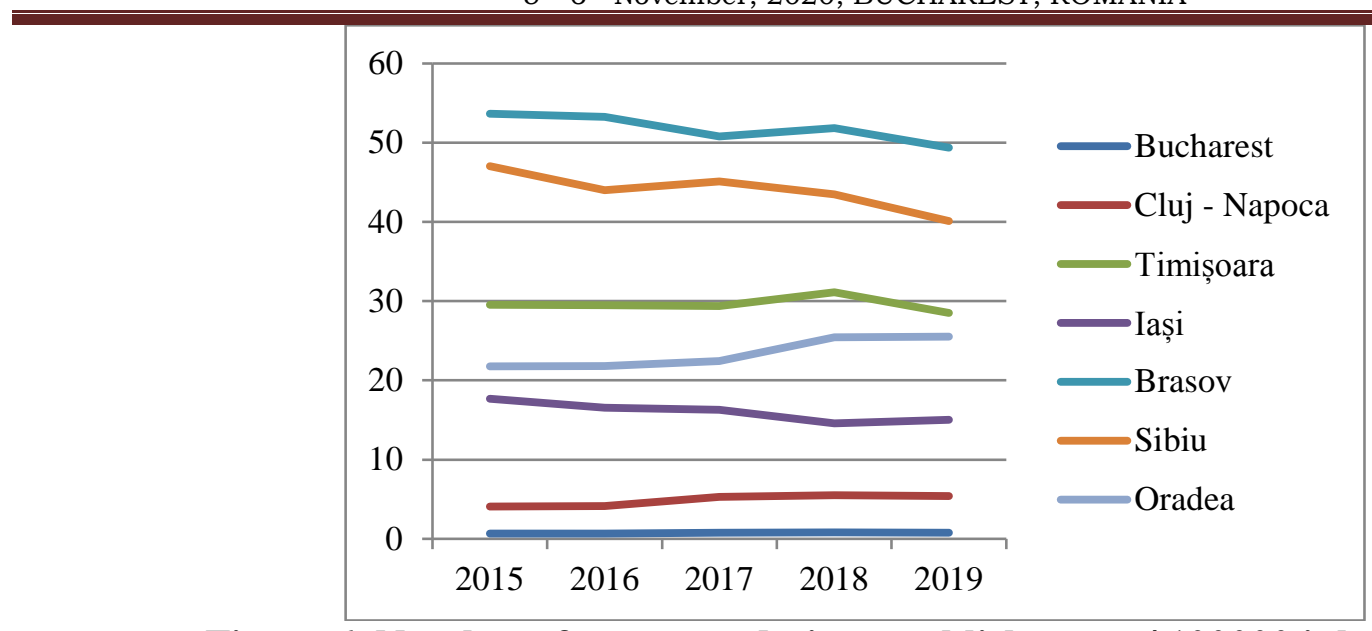

Figure 6. Number of accommodation establishments / 100000 inhabitants

Source: own elaboration using data from INSSE (n.d.)

On the other hand, even if Cluj-Napoca doesn't enjoy a large number of accommodation establishments, according to Figure 7, it records one of the highest in terms of nights spent by tourists in the accommodation establishments, proving a real interest for this city. Braşov and Sibiu keep their leading positions and the general trend is positive for each city, except Oradea, but these results can be motivated by the cancelation of international flights from Oradea’s airport in 2018.

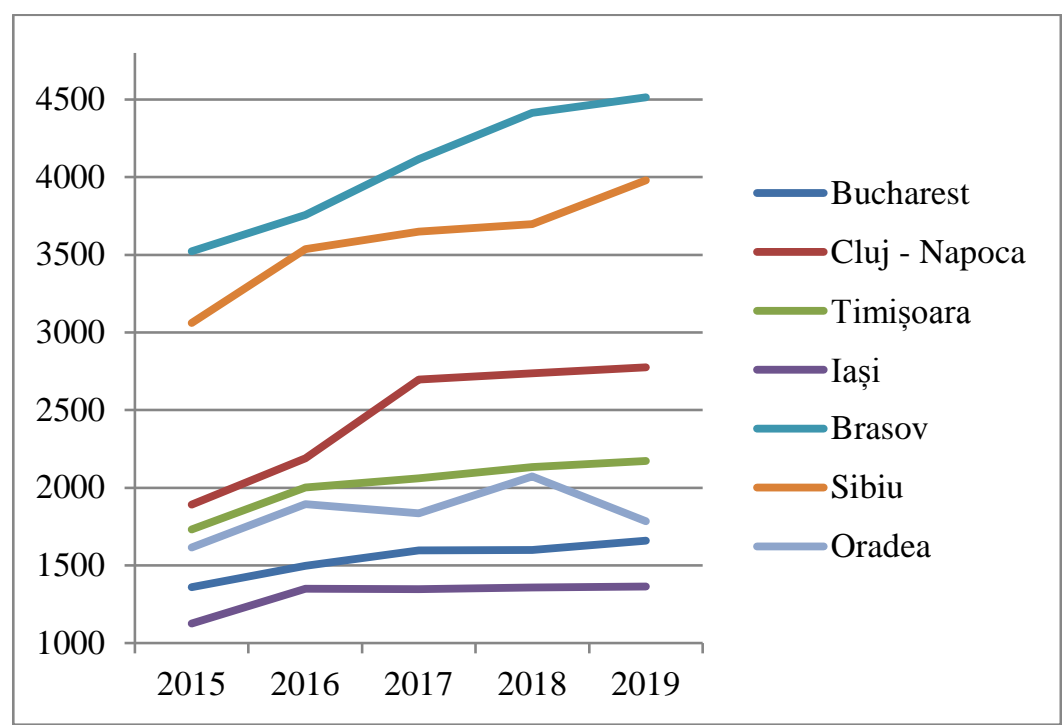

Figure 7. Number of nights spent in the accommodation establishments / 1000 inhabitants Source: own elaboration using data from INSSE (n.d.)

At first sight, the observation of the collected data doesn't prove a correlation between the developments as creative cities and tourism; the most developed creative cities don't record the highest values in terms of tourism, but these facts could represent unexplored potentials. However, further research is needed to be conducted and we should highlight that the creative tourism's success does not represents a "recipe" suitable for any city, regions or country, "creative tourism is not based in a unique model which can be reproducible in different environments. If creativity confers power to a place, creative tourism that works successfully in a place can fail in another with similar characteristics if simple transpositions of models occur. Creative tourism seeks the possibility for each place to structure one unique and not reproducible model” (Molina in Ferreira Carvalho et al., 2019). 


\section{CONCLUSIONS}

The cultural heritage, both tangible and intangible, provides reason and commodities for the tourism industry, the cultural tourism enjoying the benefits of continuous change and demand, and rather an independence from seasonality. Yet the tendency for cultural tourism to concentrate in the proximity of major tangible heritage sites "raises problems of visitor management and negative impacts on local communities" (Richards, 2020a) such as, traffic congestions, pollution, high prices and rents, etc. . In this context the creative tourism appears as a solution to the crowded cultural destinations, and also to the regular passive activities common to the cultural tourism. The creative tourism emerges and develops within the cultural tourism as a sector that satisfies higher and complex demands from the travellers; in this case the tourist is no longer a passive visitor, he becomes an active traveller that seeks participation and involvement in the local culture of the destination. The creative tourism implies activities of crafting tourists' skills and developing their creative potential through the process of co-creation touristic products and services for their own consumption; is this process creativity represents the catalyst and it "is arguably not just an end in itself, but also a means to develop distinction, economic spin-off and authenticity” (Zukin in Richards, 2011). These emotional and spiritual treats are essential for the evolved and well-educated tourist, when following a certain lifestyle and the consumption practices mark distinction and self-expressiveness.

The creative tourism practices are designed for those who seek authenticity of a certain place, an escape from the ordinary life, living and doing things that natives usually do. These practices depend on the local culture, and the intangible heritage can be explored in cities and rural areas, as well. This aspect has to be stressed out due to the numerous opportunities created for the people living in villages, the creative tourism having a great potential in generating job creation and revenues so the villagers should no longer migrate to towns and cities.

Even if the creative tourism exploits culture, creativity, skills and talent, this industry is not a creative one; it is not included in the creative economy, because its goods and services are not objects of intellectual property rights. However, there is a strong connection between the creative tourism and several cultural - creative industries, a bidirectional cause-effect relationship. In some cases, the creative industries mark a certain place e.g. film production, and thereafter the creative tourism flourishes in that place; in other cases, the creative tourism practices attract members of the creative class and boost the creative economy, maintaining a continuous development and attractiveness of the destination. Certainly, these industries - creative tourism and creative industries - enhance one another, working together as in vicious circle.

The active involvement in the local culture during holiday is not a new practice; these types of activities are known to be conducted since 1996 but started to be recognised as creative tourism only after the year of 2000. Creative tourism practices are conducted all around the world, but the niche feature of the sector provides only a low promotion and so, low visibility, among the tourism practices. In Romania, for example, there are few organizations and places where the travellers could escape from the monotonous schedule of the regular visitors. In these times of COVID-19 pandemic, and tourism being one of the hardest-hit industries, the unexploited potential of the Romanian creative tourism presents opportunities for economic recovery. However nowadays conditions demand certain hygiene and safety measures in order to prevent the infection with the virus since the creative tourism implies networking and human interconnection. Even if the practices are limited, the memories of great experiences, based on participation, engagement and involvement, lead to customers' satisfaction, and contented clients are likely to return and to recommend the services.

International examples are available to offer models for the development of creative tourism. Portugal offers a successful model in the development of a city by creating opportunities and enhancing the creative economy in the area. This development model belongs to Obidos, the various creative strategies lead also to the creation of numerous cultural events which comprise practices of creative tourism. Considering the relationship and the coexistence of the creative and cultural industries, on 
one hand, and the creative tourism, on the other hand, an analysis of several Romanian cities and their touristic potential was mandatory. The collected data do not show a direct relationship between the dimension of the local creative economies and those of the local tourism, but further and more complex investigations are needed.

\section{REFERENCES}

Al-Ababneh, M. \& Masadeh, M. (2019). Creative Cultural Tourism as a New Model for Cultural Tourism. Journal of Tourism Management Research, 6 (2), 113. Doi: 10.18488/journal.31.2019.62.109.118

Arsenal Park, (n.d.). Despre noi. Retrieved August 18, 2020 from: https://arsenalpark.ro/despre-noi/ Barcelona Creative Tourism (n.d.). About Barcelona Creative Tourism. Retrieved August 22, 2020 from https://www.barcelonacreativa.info/homepage/about-barcelona-creative-tourism/

Borg Design, (n.d.), Lista firmelor din România. Retrieved August 30, 2020 from: https://membri.listafirme.ro/statistici-economice.asp\#selectie

Bruno, C. \& Canina, C. (2019). Creativity 4.0. Empowering creative process for digitally enhanced people. The Design Journal, 22, 2122. DOI: 10.1080/14606925.2019.1594935

Creative Tourism Network, (n.d.), Barcelona, Spain. Retrieved August 22, 2020 from http://www.creativetourismnetwork.org/barcelona/

Culture Action Europe (n.d.). Farm Cultural Park. Retrieved August 23, 2020 from https://cultureactioneurope.org/projects/tell-us-a-story/farm-cultural-park/

Happ, E. \& Toth, A. (2017). Opportunities of an Industrial City in the Leisure Tourism. World Academy of Science, Engineering and Technology International Journal of Social and Tourism Sciences, 11 (10), 2387

EUROSTAT, (2019). Culture statistics. 2019 Edition, 32. Retrieved August 17, 2020, from https://ec.europa.eu/eurostat/documents/3217494/10177894/KS-01-19-712-ENN.pdf/915f828b-daae-1cca-ba54-a87e90d6b68b

Ferreira Carvalho, R. M., Martins da Costa, C. M., \& Alves Pedro Ferreira, A. M. (2019). Review of the theoretical underpinnings in the creative tourism research field. Tourism \& Management Studies, 15(SI), 11-22, Doi: https://doi.org/10.18089/tms.2019.15SI02

Higgs, P., Cunningham, S., \& Bakhshi, H. (2008). Beyond the creative industries: Mapping the creative economy in the United Kingdom, NESTA - Making innovation flourish, 22. Retrieved August 15, 2020, from: https://media.nesta.org.uk/documents/beyond_the_creative_industries_report.pdf

Hotels.com, (n.d.). James Bon Island. Island in PhangHga Bay. Retrieved August 20, 2020 from: https://www.hotels.com/go/thailand/james-bond-island

INSSE, (n.d.). Turism. Retrieved August 29, 2020 from: http://statistici.insse.ro:8077/tempo-online/ Lord of The Ring Tours, (n.d.). Epic Adventures to the Real Middle Earth and back Again. Retrieved August 18, 2020 from: https://lordoftheringstours.co.nz/?gclid=Cj0KCQjwhIP6BRCMARIsALu9LfnCHEv59Z6SL7u aKiqZmld4Cyi69nstkA9W-E8GsiD2xEVncBZLSfYaAnqwEALw_wcB

Lorenzen, M. \& Andersen, K. V. (2012). Different creative cities: Exploring Danish data to adapt the creative class argument to small welfare economies. Creative Industries Journal, 4 (2), 123. Doi: 10.1386/cij.4.2.123_1

Martinaitytė, E. \& Kregždaitè, R. (2015). The factors of creative industries development in nowadays stage. Economics and sociology, 8 (1), 56, DOI: 10.14254/2071- 789X.2015/8-1/5

Millán Vázquez de la Torre, M. G., Millán Lara, S., \& Arjona-Fuentes, J. M. (2019). Flamenco Tourism from the Viewpoint of Its Protagonists: A Sustainable Vision Using Lean Startup Methodology. Sustainability, MDPI, Open Access Journal, 11(21), 1, 4. Doi: 10.3390/su11216047 
Musikyan, S. (2016). Chapter 3.3 Óbidos as a creative city and 3.4 Creative events in Óbidos. The Influence of Creative Tourism on Sustainable development of Tourism and Reduction of Seasonality. 46-62. Retrieved August 25, 2020 from: https://iconline.ipleiria.pt/bitstream/10400.8/2147/1/Final_thesis-Srbuhi\%20updated.pdf

Pattaya Mail. Creative Tourism in Thailand - An Introduction through Creative Villages. Retrieved August 21, 2020 from https://www.pattayamail.com/travel/creative-tourism-in-thailand-anintroduction-through-creative-villages-29805

Pine II, B. J., Gilmo, J. H. (1998). Welcome to the Experience Economy. Harvard Business Review, Available at: https://hbr.org/1998/07/welcome-to-the-experience-economy

Richards, G. (2011). Creativity and the tourism. The state of the art. Annals of Tourism Research, 38 (4), 1225, 1231, 1237, 1238, 1239, 1245. Doi: 10.1016/j.annals.2011.07.008.

Richards, G. (2020a). Placemaking through creative tourism, 5-6. Retrieved August 10, 2020, from: https://www.researchgate.net/publication/339141137

Richards, G. (2020b). Designing creative places: The role of creative tourism. The Annals of Tourism Research, 85. Doi: https://doi.org/10.1016/j.annals.2020.102922 . Retrieved on August 01, 2020, from: https://www.sciencedirect.com/science/article/pii/S0160738320300669

Richards, G., Raymond, C. (2000). Creative tourism. ATLAS News, p. 18.

Richards, G., Wilson, J. (2006). Developing creativity in tourist experiences: A solution to the serial reproduction of culture? Tourism Management (27), p. 1424.

Romania Travel. Explore. Retrieved August 30, 2020 from: http://www.romania.travel/en/

Sava, D. (2020). Economia creativă - Motor de creștere și dezvoltare economică a României. Presa Universitară Clujeană. p. 118-119, Retrieved August 29, 2020 from: http://www.editura.ubbcluj.ro/bd/ebooks/pdf/2652.pdf

Sava, D. \& Bădulescu, A. (2018a). Creative and cultural sector: Focus on Romania. Proceedings of the 32nd International Business Information Management Association Conference (IBIMA), p. 2565

Sava, D. \& Bădulescu, A. (2018b). Dimensions and performances of the creative economy in Romania. Proceedings of the $12^{\text {th }}$ International Management Conference "The Role of Management in the Economic Paradigm of the XXI ${ }^{\text {st }}$ Century”, Bucharest, p. 223, Retrieved August 20, 2020 from http://conferinta.management.ase.ro/archives/2018/pdf/2_3.pdf

Sigala, M. \& Leslie, D. (2005). International Cultural Tourism: management, implications and cases, Elsevier Butterworth-Heinemann, Oxford, p. 5, 6, 7, 19, 41, 154, 238.

Ta, D. T. \& Yang, C. H. (2019). Impact of interactive service on international customers' behavior intentions on local tourism service in Vietnam. International Journal of Business and Information, 14(1), p. 160.

Visit Tara Oasului, (n.d.). Vama - the centre of ceramic. Retrieved August 23, 2020 from: https://www.turism-taraoasului.ro/en/vama-the-centre-of-ceramic/

Vlăduţiu, I. (1976). Turism cu manualul de etnografie, Sport-Turism, Bucharest, p. 15.

UNESCO, (n.d). Intangible cultural heritage, Retrieved August 11, 2020 from: https://ich.unesco.org/en/lists?text=\&country[]=00182\&multinational=3\&display1=inscriptionI D\#tabs

UNCTAD, (2008). Creative economy report - The challenge of assessing the Creative Economy: towards Informed Policy - making. p. 11, Retrieved August 13, 2020 from http://unctad.org/en/Docs/ditc20082cer_en.pdf

Wildventure, (n.d.). Casa Bătrână: o vacanță de poveste într-o casă tradițională din Apuseni, Retrieved August 30, 2020 from: https://www.wildventure.ro/cazare-casa-batrana-apuseni/ 